\title{
SPERM MORPHOLOGY AND SPERMATOGENESIS IN THE TUBE-WORM POMATOLEIOS KRASSII (POL YCHAETA: SPIROBRANCHINAE) FROM THE SUEZ BAY, EGYPT.
}

\author{
Mohamed S. Barbary \\ Zoology Department, Faculty of Science, Zagazig University
}

Key words: sperm morphology, spermatogenesis, tube worm, Pomatoleios, Suez Bay.

\begin{abstract}
7 The mature sperm morphology and spermatogenesis ultrastructure 1 have been fully described in Pomatoleios krassii, which is a spirobranchian polychoaete attached to rocks, wrecked boats, rods and hard substrates at some polluted sites on Suez Bay coast. Sperms develop in the coelom as free-floating plasmodial cells. At the end of spermatogenesis, mature sperms float freely in the coelom. The spermatogonia are relatively large in size (13 $\mu$ in diameter). The spermatozoon of the present species differs from that of other polychaete species by having a large head (6 $\mu$ in length) formed of rounded nucleus and large acrosome which forms a large curved terminal cap on the nucleus. This may be an indication that fertilization occurs by some mechanisms that limit exposure of such fragile gametes to any possiple pollution. Meanwhile, female of P.kraussii protects its eggs with a jelly mass attached to the branchial crown, and the sperm is required to penetrate the matrix of egg mass. The large pair of mitochondria $(2 \mu$ in diameter) and presence of two pairs of proximal and distal centrioles which are not recorded so for in previous studies, as well as the long tail may be correlated with a characteristic movement of the sperm to reach female branchial crown, where the egg masses are found.
\end{abstract}

\section{INTRODUCTION}

The reproductive biology of invertebrate species continues to receive a great deal of attention (Brafield \& Chapman, 1967; Gibbs, 1971; Olive 1971; Afzelius, 1972; Giangrande \& Petraroli, 1991; Tunnicliffe, 
1991; Echelbarger \& Young, 1997 \& 2002; Giangrande, 1997; Tyler \& Young, 1999).

The reproductive biology of Polychaeta shows a remarkable diversity of reproductive attributes and life history features ( Shroeder and Hartman,1975 ; Wilson, 1991) and offers abundant opportunities to study the evolution of reproductive mechanisms.Giangrand (1997) stated that the entire life history is known for only about 3\% of recorded polychaete species. Recently, Echelborger et al. (2001) described the reproductive biology of the hesionid polychaete Hesiocaeca methanicola.

In contrast to the richly studied reproductive biology of some polychaete worms, relatively few investigations have been concerned with the process of gametogenesis particularly in Spirobranchinae group ( Olive, 1971; Hutchings, 1973; Bertout, 1977; Heacox \& Schroeder, 1981; Wilson1991; Mona, 1992; Echelbarger and Young, 1997 \& 1999 ; Echelbarger et. al. 2001).

Many studies were concerned with sperm morphology and spermatogenesis of polychaete groups except spirobranchinae (Franzen, 1975; Chughtai, 1986; Echelbarger and Grassle, 1987; Rouse \& Jamieson, 1987; Jamieson \& Rouse, 1989; Rice, 1992; Rouse, 1992 and 1995; Bininger \& Le pennec, 1997; Hodgson et al., 1998; \& Echelbarger \& Young, 2002).

The studies of reproductive biology of some marine invertebrate species can be challenging, especially direct observations of spawning and fertilization. However, sperm ultrastructure can have predictive value in indirectly assessing possible fertilization mechanisms, because sperm morphology is highly correlated with the biology of fertilization (Franzen, 1956). Sperm structure is also widely used in the analysis of phylogenetic relationships within the Polychaeta (Jamieson \& Rouse, 1989 ; Rouse, 1995; Hodgson et al., 1998).

Beninger \& Le Pennec (1997) and Echelbarger \& Young (2002) noted that, sperm ultrastructure from species occupying deep sea reducing environments can be particularly indicative, when compared to spermatozoa of related taxa from more conventional habitats.

The unusual polychaete spermatozoan morphology has evolved due to the hypotoxic environment in which the adult live and that fertilization biology is likely modified in some way to minimize sperm exposure to high level of toxins (Echelbarger \& Young, 2002). 
The present species was found to contain high levels of heavy metals that might affect its vital functions including spermatogenesis (Ghobashy et al. 2002).

In Egypt, few studies concerned with the gametogenesis of Polychaeta, including those of Barbary (1992) on the nereid Nereis (Neanthes) brandti and Mona(1992) on the serpulid Hydroides dirampha which they were collected from Lake Timsah to study their reproductive cycles. On the other hand, Mona et al. (1994) carried out ultrastructural investigations of $H$. dirampha spermatogenesis to complete its reproductive biology.

In the present study, the ultrastructural morphology of mature sperm and spermatogenesis of Pomatoleios kraussii, which inhabits the Suez Bay waters was hereby examined to provide a basic information about such issue that might help in the taxonomy and phylogeny of such polychaete species.

\section{MATERIAL AND METHODS}

Adult live worms of Pomatoleios kraussii were collected from the Suez Bay waters near the shore, at depth of $50 \mathrm{~cm}$ during July 2005; where the most abdominal segments are full by gametes. The samples were immediately transferred in their tubes to the laboratory in glass containers containing cold $\left(8^{\circ} \mathrm{C}\right)$ filtered sea water, then the living worms were removed from their natural tubes. The sex of specimens was determined by puncting the body wall with a fine needle and examining the extruded coelomic contents under a compound microscope for the presence of sperms, then the mature males $(1.5-2 \mathrm{~cm})$ were selected for fixation. For histological investigation, paraffin sections were cut and stained by haematoxylin and eosin. For electron microscope investigation, cross sections of $6-8 \mu$ of abdominal segments containing coelomic sperms were cut. The tissue samples were immersed for $1.5 \mathrm{~h}$ at room temperature in $2.5 \%$ glutaraldehyde buffered with Milloning's $0.4 \mathrm{M}$ phosphate buffer fluid at $\mathrm{pH}$ 7.4. The samples were post fixed for $1 \mathrm{~h}$ at room temperature in $10 \%$ osmium tetroxide in $0.1 \mathrm{M}$ phosphate buffer plus $1 \% \mathrm{NaCl}$ at $\mathrm{pH}$ 7.2. Samples were then dehydrated in ascending concentrations of ethanol to 100\%, immersed in Epon 812. Thick and thin sections were cut on a Reichert ultramicrotome. The thick sections were stained with Ehrlich haematoxylin, while thin sections were stained with uranyl acetate and lead citrate and examined in a Philips 201 transmission electron microscope. 


\section{RESULTS}

The germ cells of Pomatoleios kraussii enter the coelom in the early stages of gametogenesis, and in all specimens examined, the coelomic cavity was highly stocked with gametes at all stages of development (Figs. 1and 2).

Pomatoleios kraussii like most polychaete worms, has an unusual dispersed testes, the gametic cells are derived from a type of testicular cells which occur in contact with the coelomic epithelium lining the muscles and gut (Fig. 3).

The ultrastructural investigation of spermatogonia revealed that they are large and spherical in shape (13 $\mu$ in diameter) with large rounded nucleus (Figs. 2 and 4). The nuclear chromatin appears occupying the full nucleus, while the cytoplasm is limited and contains many mitochondria and ribosomes (Fig. 4).

The spermatocyte is relatively spherical, containing large nucleus with finely diffuse chromatin with a single nucleolus which occurs centrally and nuclear pores appear on the nuclear membrane (Fig. 5). Its cytoplasm has a few organelles mainly mitochondria and ribosomes.

The early spermatid has spherical nucleous with densely staining chromatin and large mitochondria and a number of proacrosomal granules (Fig. 6). As spermiogenesis proceeds, chromatin condensation results immoderately within a dense, spherical and large nucleus, while a small cone-shaped acrosomal vesicle projects from the cell surface (Fig. 7). At this stage of spermatid development, the chromatin condense perinuclearly, and the cytoplasm is devoid from mitochondria which migrate to the base for association with the developing flagellum. As the spermatid develops, the acrosomal vesicle enlarges anteriorly and contains elongated acrosomal material (Fig. 8). The acrosomal material expands over the nucleus in a cap-shaped structure and attaches to the nuclear membrane with many fibres (Fig. 9). At this stage, the nucleus appears very large with little amount of cytoplasm, while the chromatin is highly condensed (Fig. 10).

At the late stage of spermatid development (Fig. 11), the acrosomal vesicle becomes large with two lateral projections, each one has a straight lateral subacrosomal organelle connected with the nuclear membrane, while a densely stained nucleus appears, the acrosomal vesicle and nucleus appear surrounded by thick sheath (Fig. 11).

As the sperm develops, the lateral subacrosomal organelles enlarge (Figs. 12 and 13) until finally fuse with the acrosomal material. The 
connection of acrosomal and subacrosomal organelles with the nuclear membrane by many filaments appears in this stage. The nucleus appears as oval body invaginated posteriorly, the mitochondria aggregate and migrate forming a pair of rounded structures in the middle-piece (Fig. 13).

The mature sperm has an oval posteriorly invaginated nucleus, with a curved acrosome, giving the sperm head of $5 \mu$ in length (Fig. 14). The acrosome appears away from the nucleus but connected with it by many fibers (Figs. 13 and 14). The middle-piece (2.5 $\mu$ in length) is large and contains a pair of large rounded mitochondria, within a shallow nuclear fossa, a centriolar complex (Figs. 14 and 15) and the associated flagellum (Fig. 16). The centriolar complex consists of anteriorly proximal centriole and posteriorly distal one, joined together by dense stained satellite connectors in peripendicular manner (Fig. 14). Figure 15 illustrates that each of proximal and distal centrioles is composed of two horizontally granules, the distal centriorlar granules become associated with the anterior region of the tail.

The sperm tail ( $9 \mu$ in length) elongates from the posterior region of the middle-piece as a long flagellum (Fig. 16), composed of a central dense fibre surrounded by clear zone and covered with dense peripheral fibre (Fig. 17). The tail is blunt anteriorly and pointed posteriorly (Fig. 16). In longitudinal section of the tail, the peripheral fibre appears broad, having many longitudinal microtubules connected to the central fibre by many transverse satellite rays (Fig. 17). In cross section, the tail shows $9+2$ arrangement of microtubules The microtubules appear encircling the central fibre and covered by thick and clear sheath; the satellite rays extend to connect the central fibre through the clear zone (Fig. 18).

The mature sperms appear in parallel manner, forming separated and scattered aggregations in the coelomic cavity (Fig. 19). The heads of mature sperms arrange towards one side and the tails towards the other side (Fig. 20).

\section{DISCUSSION}

Pomatoleios kraussii is the dominant polychaete species in Suez Bay coast, and very common at the intertidal zone, attached to rocks, wrecked boats, rods and hard substrates (Belal, 2001). Limited information is yet available on the reproductive biology of shallow-water polychaetes (Giangrande, 1997), especially spermatogenesis and sperm morphology except for a light microscope study on Nainereis laevigata by Giangrande \& Petraroli (1991), in which they reported developing coelomic sperm platelets. Barbary (1992) described the reproduction and 
gametogenesis of Neanthes brandti collected from Lake Timsah. Mona (1992) explained the oogenesis of Hydroides dirampha. Therefore, no information is, so far, available on the reproductive biology as well as gametogenesis of Pomatolieus kraussii.

The gametic cells of Pomatolieus kraussii are derived from groups of cells which are attached to the coelomic epithelium lining the coelomic cavity, and released into the coelomic fluid at an early stage of development and differentiation. These simple testes have also been described in many polychaete groups as Cirratulidae (Gibbs, 1971); Ophellidae (Ochi et al., 1977); Syllidae and Terebellidae (Echelbarger, 1975); Serpulidae (Potswald, 1967 ; Mona, 1992) and Nereidae (Barbary, 1992).

Regarding to spermatogonia of many polychaetes, Potswald (1967) showed that the male gonads of Spirorbis contain germ cells which have an almost spherical nucleus with scattered chromatin and more cytoplasm. Mona et al. (1994) postulated similar description of spermatogonia in Hydroides diramph with little cytoplasm, the spermatogonia of Pomatolieus kraussii in the present study appeared similar to that described in H.dirampha by Mona (1992) but larger in size.

Rice (1992) made some ultrastructural observations of mature sperm morphology for two orbiniid species (Leitoscoloplos pugettensis and $L$ elongates). Both species have sperms characterized by rounded head with a simple cap-like acrosome, four to five spherical mitochondria in the middle-piece, and a tail with 9+2 arrangement At the same time, Rouse (1992) stated that the nucleus of four sabellid species have nuclei developed into 4 connected rods. Rice (1992) noted that Leitoscoloplos pugettensis possesses an eccentric flagellum, On the other hand, Echelbarger \& Young (2002) noted that the mature sperm of orbiniid species Methanoaricia dendrobranchiata has an elongated nucleus and nucleolus as well as a greatly elongated and curved acrosome. This acrosome was considered the longest recorded for any polychaete species, where it reached $19.5 \mu$. in length. Large acrosome also has been reported by Jamieson \& Rouse (1989) and Blake (1993). These studies demonstrated a statistical correlation between sperm acrosome length and thickness of the vitelline envelope of the egg. On the other hand, Eckelbarger \& Grassle (1987) found a high negative correlation between sperm acrosome length and egg dimensions in capitellid polychaetes. Mona et al. (1994) stated that the ripe spermatozoon of Hydriodes dirampha is relatively short, with elongated nucleus and blunt rounded 
acrosome. They considered the sperm to be intermediate between primitive and modified types. In the present study, the head (acrosome and nucleus) appeared large and rounded due to the large rounded nucleus and enlarged acrosome which forms a large curved terminal cap-like structure on the nucleus. However, the large acrosome in Pomatolieus kraussii sperm is not yet correlated with attributes of the egg, because the egg closely resembles that observed in many shallow-water polychaete species; including Leitoseoloplos pugettensis (Rice, 1992), Hydroides dirampha (Mona et al., 1994) and Leitoseoloplos fragilis (Echelbarger et al., 2001), where all of them have simple cap-like acrosome. P.kraussii is an aerobic organism that lives in a microhabitat that is polluted with many heavy metals (Belal, 2001). Its anterior gills are hypertrophoid apparently to facilitate gas exchange, and the gill cells contain many mitochondria and electron-dense organelles that may play a role in metal detoxification. This suggestion comes in accordance with the finding of Hourdez et al. (2001). The present study showed that the head and large acrosome in P.kraussii is an indication that fertilization occurs by some mechanisms that limit exposure of gametes to high pollution levels. Many polychaete species release their eggs into jelly coated egg masses or cocoons (Blake, 1996), so it is possible that P.kraussii protects its eggs from such environment with a jelly mass attached to the branchial crown. This would probably require the sperm to penetrate a matrix in the egg mass to achieve fertilization and illustrates the presence of embryos of this species in the branchial crown during early stages of development. This conclusion agrees with that of Knight-Jones \& Bowden (1984), where they reported specimens of the sabellid Perkinsiana rubra having sperms with round nucleus and long acrosome and holding the embryos in the branchial crown. Rice (1992) stated that the eggs of P.rubra attach in a jelly mass in the crown.

Mona et al. (1994) noted that the middle-piece of the mature sperm of Hydroides dirampha is short and contains a pair of subspherical mitochondria and a pair of centrioles, but in some other species of Polychaeta, the middle-piece has four, five or six spherical mitochondria (Eckelbarger \& Young, 1999 and 2002). The presence of a large pair of rounded mitochondria in middle-piece of Pomatolieos kraussii may be correlated with the highly swimming of sperms towards eggs in the female.

The present study showed also that the proximal and distal centrioles are double in the middle-piece of Pomatolieous kraussii, 
sperm. This was not met within any studied polychaete species, which may be correlated with a characteristic movement of such sperm to reach female branchial crown, where the egg masses are found.

Mona et al. ( 1994 ) found a short tail in Hydroides dirampha sperm, but in the present species, the sperm tail was found to be relatively long, and thought to play an important role in controlling the sperm movement.

The sperm morphology may thus have taxonomic and phylogenetic value as seen in Spionidae, Capitellidae, and Histriobedellidae (Jamieson \& Rouse, 1989). On the other hand, Rouse (1995) used the sperm morphology as a characteristic feature in ten fabrician genera. Blake (2000) reported that Methanoaricia dendrobranchiata is difficult to place in any known polychaete family, but it has more affinities to the Orbiniidae than any other on the bases of life history and sperm morphology. Therefore, the present description of sperm morphology and spermatogenesis might help in the taxonomy and phylogeny of related polychaete species.

\section{REFERENCES}

Afzelius, B.A. (1972). Sperm morphology and fertilization biology. In the genetics of the spermatozoon (Eds R.A. Beatty, S. Gluecksohn-Waelsch), pp. 131-143, Edinburgh.

Barbary, M.Sh. (1992). Surveillance and ecological studies on the polychaetes in lake Timsah (Suez Canal, Egypt). Ph.D. Thesis, Zagazig University, 249 pp.

Belal, A.A.M. (2001). Ecological studies on the polychaetes in Suez Bay. Ph.D. Thesis, Zagazig University, 295pp.

Beninger P.G. and Le Pennec M. (1997). Reproductive characteristics of a primitive bivalve from a deep-sea reducing environment: gaint gametes and their significance in Acharx alinae (Cryptodonta: Solemyidae). Mar. Ecol. Prog. Ser. 157: 195206.

Bertout, M . ( 1977 ). Spermatogenesis de Nereis diversicolor O.F. Müller ( Annelida, Polychaeta ) . Biol Cel - Lulaire,30:211- 216 
Blake, J.A. (1993). Life history analysis of five dominant infaunal polychaete species from the continental shelf off North Carolina. J. Mar. Biol. Assoc. U.K. 73:123-141.

Blake, J.A. (1996). Family Orbiniidae Hartman, 1942. pp.1-26 in Taxonomic Atlas of the Benthic Fauna of the Santa Maria Basin and Western Santa Barbara Channel J.A. Hilbig, and P.H. Scott, eds. Santa Barbara Museum of Natural History, Santa Barbara. CA.

Blake, J.A. (2000). A new genes and species of polychaete worm (Family Orbiniidae) from methane seeps in the Gulf of Mixico. With a review of the systematics and phylogenetic interrelationships of the genera of Orbiniidae Cah. Biol. Mar. 41: 435-449.

Brafield, A.E. and Chapman G. (1967). Gametogenesis and breading in a natural population of Nereis virens. J. Mar. Biol. Ass. U.K. 47: 519-527.

Chughtoi, L. (1986). Fine structure of spermatozoa in Perkinsiana rubra and Pseudopotamilla veniformis (Sabellidae: Polychaeta). Acta 2001 : 67: 165-171.

Echelbarger, K.J. (1975). A light and electron-microscope investigation of gametogenesis in Nicolea zostericola (Polychaeta: Terebellidae). Mar. Biol., 30: 353-370.

Echelbarger, K.J. and Grassle, J.P. (1987). Spermatogenesis, sperm storage and comparative sperm morphology in nine species of Capitella capitomastus (Polychaeta - Capitellidae). Mar. Biol. 95: 415-429.

Echelbarger, K.J. and Young, C.M. (1997). Ultrastructure of the ovary and oogenesis in the methane-seep mollusce, Bathynerita naticoidea (Gastropoda: Neritidae) from the Louisiana slope. Invertebr. Biol. 116: 299-312.

Echelbarger, K.J. and Young, C.M. (1999). Ultrastructure of gametogenesis in a chemosynthetic mytilid bivalve (Bathynerita childressi) from a bathyal, methane seep 
environment (Northern Gulf of Mexico). Mar. Biol. 135: 635646.

Echelbarger, K.J. and Young, C.M. (2002). Spermiogenesis and modified sperm Morphology in the "seepworm" Methanoaricia dendrobranchiata (Polychaeta: Orbiniidae) from a methane seep environment in the Gulf of Mixico: Implications for fertilization biology. Biol. Bull. 203: 134-143.

Echelbarger, K.J.; Young, C.M.; Ramirez Liodra, E.; Brooke, S. and Tyler, P.A. (2001). Gametogenesis, spawining behavior, and early development in the "iceworm" Hesiocaeca methanicola (Polychaeta: Hesionidae) from methane hydrates in the Gulf of Mixico. Mar. Biol. 138: 761-775.

Franzen, A. (1956). On spermiogenesis, morphology of the spermatozoon, and biology of fertilization among invertebrates. Zool. Bidr. Upps. 31: 355-482.

Franzen, A. (1975). Fine structure of spermiogenesis in Fabricia sabella, Polychaeta, family Sabellidae. Zoon, 5: 97-105.

Ghobashy, A.A.; Badawi, H.R.; El-Sayed, A.; Barbary, M.S. and Belal, A.A. (2002). Heavy metals in coastal water, in sediment and in two polychaete species in the Suez Bay. Inter. Comfer. Biol. Sci. 2: 34-51.

Giangrande, A. (1977). Polychaete reproductive patterns, life cycles and life histories: an overview. Ocean. Mar. Biol. Ann. Rev. 35: 323-386.

Giangrande, A., and Petraroli, A. (1991). Reproduction, larval development and post-larval growth of Naineris laevigata (Polychaeta, Orbiniidae) in the Mediterranean Sea. Mar. Biol. 111: 129-137.

Gibbs, P.E. (1971). A comparative study of the reproductive cycles in four polychaete species belonging to the family Cirratulidae. J. Mar. Biol. Ass. U.K. 51: 745-771. 
Heacox, A.E. and Schroeder, P.C. (1981). A light and electronmicroscope investigation of gametogenesis in Tryposyllis pulchra (Berkeley and Berkeley) (Polychaeta: Syllidae). I. Gonad Structure and Spermatogenesis. Cell. Tiss. Res., 218: 623-639.

Hodgson, A.N.; Echelbarger, K.J. and Young, C.M. (1998). Sperm morphology and spermiogenesis in the methane-seep mollusc Bathynerita maticoidea (Gastropoda: Neritacea) from the Louisiana slope. Invertebr. Biol. 117: 119-207.

Hourdez, S.; Frederick, L.A.; Schernecke, A. and Fisher, C.R. (2001). Functional respiratory and anatomy of a deep-sea orbiniid polychaete from the Brine Pool NR-1 in the Gulf of Mixico. Invertebr. Biol. 120: 29-40.

Hutchings, P.A. (1973). Gametogenesis in a Northumber land population of Melinna cristata (Polychaeta: Ampharetidae). Mar. Biol., 18: 199-211.

Jamieson, B.G.M. and Rouse, G.W. (1989). The spermatozoa of the polychaeta (Annlida): an ultrastructural review. Biol. Rev. Comb. Philos. Soc. 64: 93-157.

Knight-Jones, P. and Bowden, N. (1984). Incubation and scissiparity in Sabellidae (Polychaeta). J. Mar. Biol. Assoc. UK. 64: 809-818.

Mona, M.H. (1992). Gametogenetic cycle of the tube worm Hydroides dirampha (Polychaeta, Serpulidae ) from Lake Timsah (Suez Canal, Egypt). Delta J. Sci., 16(1): 244-261.

Mona, M.H.; Eissa, S.H.H.; Abdel-Gawad, A.M. and Barbary, M.Sh. (1994). Ultrastructural investigation of spermatogenesis in the tube-worm Hydroides dirampha (Polychaeta, Serpulidae). J. Egypt. Ger. Soc. Zool. 13 (C ): 115-128.

Ochi O.; Kubo, M. and Sawada, N. (1977). Electron microscope study on sperm differentiation in Travisia japonica (Polychaeta). Ann. Zool. Japan., 50: 87-98. 
Olive, P.J. (1971). Ovary structure and oogenesis in Cirratulus cirratus (Polychaeta-Cirratulidae). Mar. Biol., 8: 243-259.

Potsward, H.E. (1967). An electron microscope study of spermiogenesis in Spirobis (Laeospira) morchi Levinsen (Polychaeta). Z. Zellforsch., 83: 231-248.

Rice, S.A. (1992). Polychaeta: Spermatogenesis and spermiogenesis. Pp. 129-151 in microscopic anatomy of Invertebrates, Vol.7. Annelida, F.W. Harrison and S.L. and Gardner eds. Wiley-Liss New York.

Rouse, G.W. (1992). Ultrastructure of spermiogenesis and spermatozoa of four Oriopsis species (Sabellinae, sabellidea, Polychaeta). Zool. Scr. 21: 363-379.

Rouse, G.W. (1995). Is sperm ultrastructure useful in polychaeta:systematics An example using 20 species of the Fabriciinae (Polychaeta: Sabellidae). Acta. Zool. 76: 57-74.

Rouse, G.W. and Jamieson, B.G.M. (1987). An ultrastructural study of the spermatozoa of the polychaetes Eurythoe complanata (Ampinomidae), Chymenella laseroni and Micromaldane laseroni (Maldanidae) with definition of sperm types in relation to reproductive biology. J. Submicrosc. Cytol. 19: 573584.

Tyler, P.A., and Young, C.M. (1999). Reproduction and dispersal at vents and cold seeps J. Mar. Biol. Assoc. UK, 79: 193-208.

Tunnicliffe, V. (1991). The biology of hydrothermal vents: ecology and evolution. Oceanogr. Mar. Biol. Ann. Rev. 29: 319-407.

Wilson, W.H. (1991). Sexual reproductive modes in polychaetes: classification and diversity. Bull. Mar. Sci., 48:500-516. 


\section{LIST OF FIGURES}

Fig. (1): Light micrograph of male coelomic cavity in thick section. sg. spermatogonia, st. spermatocytes, sd. spermatids, sz. spermatozoa .

Fig. (2): Light micrograph of male coelomic cavity in thick section. sg. spermatogonia, st. spermatocytes, sd. spermatids .

Fig. (3): Transmission electron micrograph showing the coelomic testicular cells (ctc) containing the gametic cells (gc) .

Fig. (4): Transmission electron micrograph of spermatogonia. n, nucleus, mt. mitochondria, cy. Cytoplasm, r. ribosomes, nm. nuclear membrane .

Fig. (5): Transmission electron micrograph of spermatocyte. n. nucleus, nu. nucleolus, nm. nuclear membrane, np. nuclear pore, cy. cytoplasm, r. ribosomes, ch. chromatin, mt. mitochondria.

Fig. (6): Transmission electron micrograph of early spermatid. n. nucleus, cy. cytoplasm, ch. chromatin, mt. mitochondria, pag. proacrosomal granules .

Fig. (7): transmission electron micrograph of early spermatid. n. nucleus, cy. cytoplasm. csh. cell sheath, av. acrosomal vesicle. ch. chromatin.

Fig. (8): Transmission electron micrograph of spermatid. n. nucleus, ch. chromatin, ssh. spermatid sheath. cy. cytoplasm. av. acrosomal vesicle. pag. proacrosomal granules.

Fig. (9): Transmission electron micrograph of spermatid. n. nucleus, am. acrosomal material, f. fibres.

Fig. (10): Transmission electron micrograph of spermatid, n. nucleus, a. acrosom, ash. acrosomal sheath, ch. chromatin, cy. cytoplasm. f fibres, fl. flagellum. 
Fig. (11): Transmission electron micrograph of late spermatid. n. nucleus, cy. cytoplasm, ssh. spermatid sheath, av. acrosomal vesicle, lp.lateral projection, sam. subacrosomal material. f. flaments.

Fig. (12): Transmission electron micrograph of late spermatid. n. nucleus, sam.subacrosomal material, am. acrosomal material, mt. mitochondria.

Fig. (13): Transmission electron micrograph of late spermatid. n. nucleus, sam. subacrosomal material, mt. mitochondria, f. flaments.

Fig. (14): Transmission electron micrograph of spermatozoa. n. nucleus, a. acrosome, nf. nuclear fossa, in. invagination, mt. mitochondria.

Fig.(15): Transmission electron micrograph of mature spermatozoa. a. acrosome, n. nucleus, mt. mitochondria, pc. proximal centriole, dc. distal centriole.

Fig. (16): Transmission electron micrograph of mature sperm. n. nucleus, mt. mitochondria, t.tail, cf. central fibre, pf. peripheral fibre.

Fig. (17): Transmission electron micrograph of longitudinal section in sperm tail. cf. central fibre, pf. Peripheral fibre, cz. clear zone.

Fig. (18): Transmission electron micrograph of transverse sections in sperm tail. cf. central fibre, mc. microtubules, lsh.clear sheath, sr. satellite rays, pf. Peripheral fibre.

Fig. (19): Transmission electron micrograph showing the parallel, separated and scattered spermatozoon agreggations in the coelomic cavity (csz).

Fig. (20): Transmission electron micrograph showing the mature sperm heads in one side and tails in the other side, h.heads,t.tails. 